\title{
Granulosa cells from pig follicles of different sizes demonstrate maturational differences in their steroidogenic responses to FSH, calcium ionophore A23187, and phorbol diester
}

\author{
V. W. Hylka and G. S. diZerega \\ Livingston Reproductive Biology Laboratory, Department of Obstetrics and Gynecology, \\ University of Southern California School of Medicine, 1321 North Mission Road, Los Angeles, \\ California 90033, USA
}

\begin{abstract}
Summary. Cultures of granulosa cells from small $(<3 \mathrm{~mm})$, medium $(3-6 \mathrm{~mm})$, or large $(8-10 \mathrm{~mm})$ pig follicles were treated as follows: (1) basal controls, (2) cyclic adenosine 3', 5'-monophosphate (cAMP) pathway agonists (pig FSH: $100 \mathrm{ng} / \mathrm{ml}$; forskolin: $10 \mu \mathrm{M}$; dibutyryl cAMP; $1 \mathrm{mM}$ ), (3) calcium ionophore A23187 (0.005-1 $\mu \mathrm{g})$, or (4) phorbol 12myristate 13-acetate (TPA; $0.05-4 \mathrm{ng} / \mathrm{ml}$ ). The combination of A23187 or TPA together with cAMP agonists was also examined in cultures of granulosa cells from follicles of different sizes. All substances were added at the time of culture, and oestradiol and progesterone were measured in the culture media after $48 \mathrm{~h}$. All cAMP agonists were most potent in their stimulation of steroidogenesis (as a $\%$ of control) in cells from small follicles $(P<0.05)$ with the exception of forskolin, which increased oestradiol in cells from large follicles to a greater extent than in cells of small follicles $(P<0.05)$ (cells from medium follicles demonstrated less stimulation than those from small follicles except in progesterone production, for which FSH was equipotent). With the exception of forskolin, however, granulosa from large follicles showed little (oestradiol) or no stimulation (progesterone) with cAMP agonists. Under basal conditions, A23187 inhibited progesterone in all groups $(P<0.05)$, and oestradiol production was reduced in granulosa cells from small follicles $(P<0.05)$, unchanged in cells from medium follicles, and significantly stimulated in cells from large follicles. A23187 inhibited the enhanced production of both hormones after administration of cAMP agonists from cells of small and medium follicles $(P<0.05)$, with inhibition significantly greater in cells of small follicles compared with medium. In cells from large follicles challenged with cAMP agonists, A23187 inhibited progesterone but stimulated oestradiol production; substitution of TPA (a protein kinase C stimulator) for A23187 gave identical results under basal or FSH-treated cultures of granulosa cells from small-, medium- or large-sized follicles. Our results suggest that TPA, A23187 and cAMP agonists modulate steroidogenesis differently in pig granulosa cells, depending on the stage of maturation of the follicle. Oestradiol production in granulosa cells from large preovulatory follicles may come under the stimulatory control of regulators of protein kinase $\mathrm{C}$ as in follicles near ovulation.
\end{abstract}

Keywords: pig; granulosa; follicle maturation; phorbol esters; calcium ionophore; steroidegenesis

\section{Introduction}

The ability of granulosa cells to secrete steroids changes during follicular maturation (Hillier et al., 1980; Ainsworth et al., 1980; Tsang et al., 1985). As the mammalian follicle develops, there are 
alterations in aromatase activity and production of oestradiol (Tsonis et al., 1984; Tonetta \& diZerega, 1989). Additionally, progesterone production increases as the follicle nears ovulation (Tsang et al., 1985). Furthermore, the follicle secretes large amounts of oestradiol just before the surge of luteinizing hormone (Foxcroft \& Hunter, 1985). Also, as the follicle enlarges, granulosa cells acquire increasing numbers of receptors for LH (Lee, 1976), an effect mediated by FSH and oestradiol.

However, very little is known about whether effectors of granulosa cell function differ depending on the maturational state of the follicle. Skinner \& Osteen (1988) cultured granulosa cells from cow follicles of different sizes and observed an increase in aromatase activity as the follicle matured, but did not observe a differential ability of FSH or insulin to cause secretion of specific proteins. Lee (1976) reported that in large pig follicles increased receptors for LH are concomitant with increased ability of LH to stimulate cAMP formation. We have found that granulosa cells cultured from small-sized follicles were more sensitive to the inhibitory actions of the phorbol ester TPA upon steroidogenesis compared with cells cultured from medium-sized pig follicles (Hylka et al., 1989).

The pig ovary is large enough to obtain large populations of granulosa cells for culture from small antral, medium antral, and Graafian follicles. Using these populations of granulosa cells cultured under serum-free conditions, we attempted to determine whether certain stimulators/ inhibitors of granulosa steroidogenesis differed in their effectiveness depending on the state of maturation of the follicle. Some of the data has been published in abstract form (Hylka \& diZerega, 1988).

\section{Materials and Methods}

Materials. Insulin from bovine pancreas, forskolin, dibutyryl cyclic AMP ( = cAMP; $\mathrm{N}^{6}-2^{\prime}-0$-dibutyryladenosine $3^{\prime}, 5^{\prime}-$ cyclic monophosphate), calcium ionophore A23187, phorbol ester (=TPA; phorbol 12-myristate 13-acetate), inactive phorbol ester analogue ( =TPA analogue; 4 $\alpha$-phorbol 12,13-didecanoate), and androstenedione were purchased from Sigma Chemical Co. (St Louis, MO, USA). Pig FSH (NIH-FSH-P2) was provided by the National Hormone and Pituitary Program, the National Institutes of Health, Bethesda, MD, USA. Medium 199 with Earle's salts, penicillinstreptomycin solution, and Fungizone were from Grand Island Biological Co. (Grand Island, NY, USA). Human transferrin came from Pentex-Miles (Naperville, IL, USA).

Cell cultures. Granulosa cells were aspirated from small $(<3 \mathrm{~mm})$, medium $(3-6 \mathrm{~mm})$, and large $(8-10 \mathrm{~mm})$ healthy follicles (non-haemorrhagic; amber coloured follicular fluid with no debris) obtained from sows at a local abattoir. Cells were routinely acquired from a collection of 150-225 ovaries, obtained within a $1 \mathrm{~h}$ period. In addition, ovaries were devoid of corpora lutea. (It should be noted that cells obtained from the different sized follicles from these ovaries may also represent various stages of atresia as well as stages of maturation. Additionally, since all the culture media contained insulin as a supplement, it is possible that some of the results could be due to interaction between agents and insulin, rather than the agents alone. However, insulin was present in all control cultures.) All procedures were performed at room temperature unless stated otherwise. Cells were washed 3 times in Medium 199 containing streptomycin $(10 \mathrm{ng} / \mathrm{ml})$, penicillin $(1000 \mathrm{IU} / \mathrm{ml})$, and Fungizone $(10 \mathrm{ng} / \mathrm{ml})$. The last wash contained Medium $199+$ antibiotics $+10 \mu \mathrm{g}$ insulin $/ \mathrm{ml}+5 \mu \mathrm{g}$ transferrin $/ \mathrm{ml}$ and $2.5 \times 10^{-7}$ M-androstenedione [M199], which was also the medium used for incubation. Viable cells (determined by trypan blue exclusion) were counted and plated at $5 \times 10^{5}$ cells per well per $\mathrm{ml}$ (24-well plates) in serum-free $\mathrm{M} 199$. Cells were incubated at $37^{\circ} \mathrm{C}$ in $5 \% \mathrm{CO}_{2} /$ $95 \%$ air. Compounds at doses determined from previous experiments (Hylka et al., 1989) were added (in $50 \mu 1$ volume) at the time of plating as follows: (a) control (M199); (b) A23187 (0.005-1 $\mu \mathrm{g} / \mathrm{ml})$; (c) pig FSH (100 ng/ml); (d) pig FSH + A23187 (0.005-1 $\mu \mathrm{g} / \mathrm{ml}) ;$ (e) forskolin $(10 \mu \mathrm{M}) ;(\mathrm{f})$ forskolin + A23187 $(0.005-1 \mu \mathrm{g} / \mathrm{ml}) ;(\mathrm{g})$ dibutyryl cAMP (cAMP) (1 mM); and (h) cAMP + A23187 $(0.005-1 \mu \mathrm{g} / \mathrm{ml})$. In a separate experiment using granulosa cells from large pig follicles, treatment groups were as follows: (a) control; (b) TPA $(0 \cdot 1-4 \mathrm{ng} / \mathrm{ml})$ or inactive TPA analogue $(4 \mathrm{ng} / \mathrm{ml})$; (c) pig FSH (100 ng); (d) pig FSH + TPA (0.1 $4 \mathrm{ng} / \mathrm{ml})$ or inactive TPA analogue $(4 \mathrm{ng} / \mathrm{ml})$; (e) forskolin $(10 \mu \mathrm{M})$; (f) forskolin + TPA $(0.1-4 \mathrm{ng} / \mathrm{ml})$ or TPA analogue $(4 \mathrm{ng} / \mathrm{ml}) ;(\mathrm{g})$ cAMP $(1 \mathrm{mM})$; and $(\mathrm{h})$ cAMP + TPA $(0.01-4 \mathrm{ng} / \mathrm{ml})$ or TPA analogue $(4 \mathrm{ng} / \mathrm{ml})$. In a third experiment, granulosa cells from small-, medium- and large-sized follicles were treated with (a) M199 (controls); (b) TPA (1-4 ng/ml) or inactive TPA analogue (4 ng/ml); (c) pig FSH (100 ng/ml); and (d) pig FSH + TPA or TPA analogue. In this last experiment, only concentrations of oestradiol were measured. Media were removed at $48 \mathrm{~h}$ after culture and frozen until assayed.

Viability of cells was examined after exposing $48 \mathrm{~h}$ cultures to trypan blue $(0 \cdot 2 \%)$ (dye added to cells in media in the wells) and examining cells microscopically (still in culture dishes). In all treatments, $85-91 \%$ of cells originally plated (compared with 1 -h cultures) were viable. 
Radioimmunoassay (RIA). Concentrations of progesterone and oestradiol in media were determined using a double-antibody RIA. Anti-progesterone antibody, ${ }^{125} \mathrm{I}$-labelled progesterone, and second antibody were obtained from Radioassay System Laboratories (Carson, CA, USA). ${ }^{125}$ I-labelled oestradiol and anti-oestradiol antibody were purchased from PANTEX (Santa Monica, CA, USA). Goat anti-rabbit gamma globulin (3\%) (second antibody) containing $4 \%$ polyethylene glycol was used as the precipitating agent. Cross-reactivity of the anti-oestradiol antibody was $<0.01 \%$ for progesterone, testosterone and androstenedione; anti-progesterone showed $0.14 \%$ crossreactivity for androstenedione, $0.1 \%$ for testosterone and $<0.01 \%$ for oestradiol- $17 \beta$. Intra-assay variation for both assays was $<7 \%$ and interassay variation $<10 \%$. Sensitivities of the assays were $3 \mathrm{pg}$ oestradiol $/ \mathrm{ml}$ and $78 \mathrm{pg}$ progesterone/ml.

Statistics. To make comparisons between granulosa cells from follicles of different size, the values in Figs 1-3 are expressed as $\%$ of control. For a reference point, cell cultures from the following follicular sizes had the following basal concentrations of oestradiol (pg) and progesterone ( $\mathrm{ng}$ ): small $=583 \mathrm{pg} / \mathrm{ml}, 26.5 \mathrm{ng} / \mathrm{ml}$; medium $=952 \mathrm{pg} / \mathrm{ml}$, $46.4 \mathrm{ng} / \mathrm{ml}$; large $=240 \mathrm{pg} / \mathrm{ml}, 1936 \mathrm{ng} / \mathrm{ml}$. Data were analysed using analysis of variance followed by Duncan's multiple range test. Tests were corrected for unequal sample size (Steel \& Torrie, 1980), and $P<0.05$ was considered significant. All graphs were drawn using GraphPAD ${ }^{\circledR}$ (GraphPAD Software, LaJolla, CA, USA) plotting and digitizing software.

\section{Results}

\section{Effects of stimulators of the protein kinase A system}

Oestradiol production was significantly stimulated by FSH, forskolin and cAMP above control levels in all groups, with the exception of cAMP which did not enhance oestradiol secretion in cells from large follicles (Fig. 1). When stimulated by FSH or cAMP, granulosa from small follicles demonstrated a greater \% increase of oestradiol from basal levels compared with cells from medium or large-sized follicles $(P<0.05)$. In contrast, granulosa from large follicles demonstrated the greatest \% elevation of oestradiol in response to forskolin $(P<0.05)$.

FSH induced an equal \% stimulation of progesterone production by granulosa from small- and medium-sized follicles (Fig. 1). However, cells from small follicles demonstrated a significantly greater $\%$ increase of progesterone in response to forskolin or cAMP compared with cells from medium-sized follicles. In contrast, granulosa cells from large follicles did not increase output of progesterone in response to $\mathrm{FSH}$, forskolin or cAMP compared with control levels.

\section{Effect of $\mathbf{A} 23187$}

A23187 significantly inhibited oestradiol in cells from small follicles, had no effect on oestradiol production in cells from medium follicles, and produced a significant enhancement of oestradiol production (7-fold increase) by granulosa from large follicles (Fig. 2a). In contrast, the ionophore inhibited basal production of progesterone in all groups of cells $(P<0.05)$; granulosa from smalland medium-sized follicles had a greater \% reduction at any dose of A23187 than did cells from larger follicles $(P<0.05)$.

\section{Effect of A23187 and FSH}

Calcium ionophore inhibited FSH-induced oestradiol production by granulosa cells from small and medium-sized follicles at doses of 0.05 to $1 \mu \mathrm{g} / \mathrm{ml}(P<0.05)$ (Fig. 2b). In this dose range, A23187 inhibited steroid secretion significantly more (as a \% of control) in cells from small- compared with medium-sized follicles. The two lowest doses of A23187 $(0.005,0.01 \mu \mathrm{g} / \mathrm{ml})$ actually enhanced FSH-induced oestradiol in cells from small follicles $(P<0.05)$ but did not affect oestradiol production by granulosa from medium-sized follicles when compared to the FSH control. In contrast, A23187 at $0 \cdot 1-1 \mu \mathrm{g} / \mathrm{ml}$ significantly increased oestradiol concentrations above FSHtreated control values (4-fold increase) in granulosa from large follicles. When progesterone was measured under these conditions, a dose-dependent inhibition occurred i in all groups $\left(P_{4 / 2}</ 2.05\right)$. 

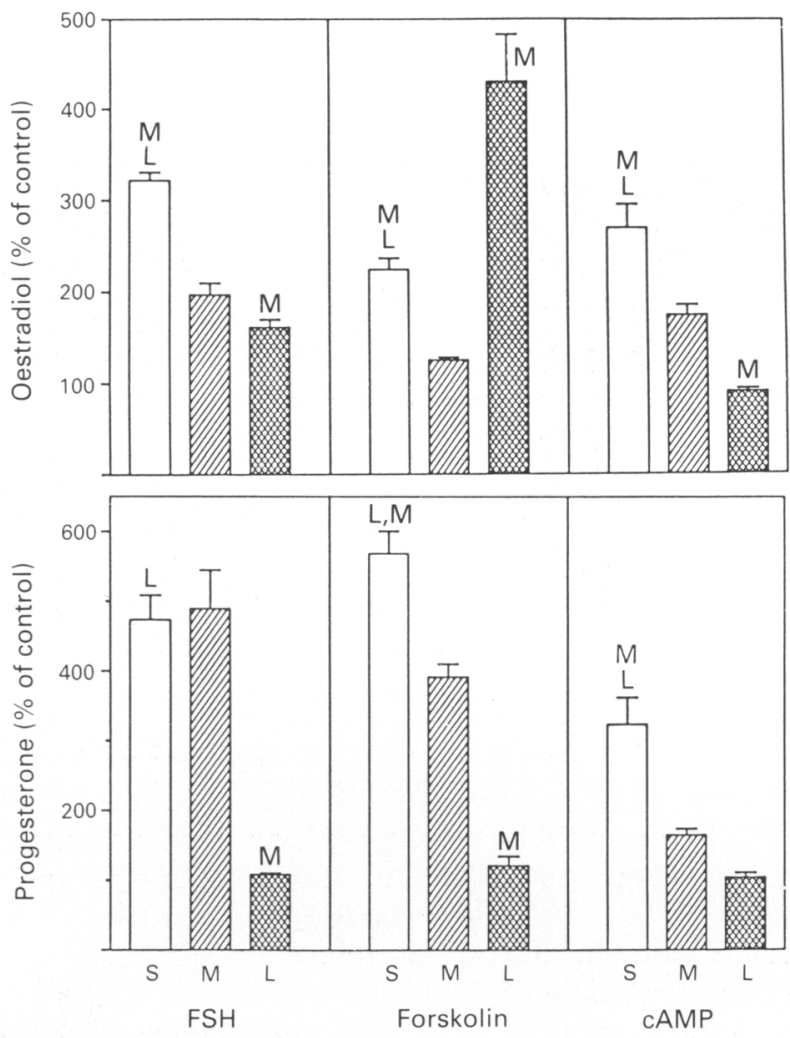

Fig. 1. Effects of pig FSH, forskolin, and cAMP on production of oestradiol and progesterone from granulosa cells of small- $(\square)$, medium- $(\square)$ and large-sized ( pig follicles. Values represent the mean \pm s.e. of 5-6 individual samples. Values are expressed as a $\%$ of the nontreated control value for each follicle size (non-treated controls $=100 \%$ for each group). An ' $\mathrm{M}$ ' or ' $\mathrm{L}$ ' on top of a bar indicates a significant difference $(P<0.05)$ from granulosa from medium or large follicles, respectively, within the same treatment. Cells were treated with $100 \mathrm{ng}$ pig $\mathrm{FSH} / \mathrm{ml}, 10 \mu \mathrm{M}$-forskolin or $1 \mathrm{~mm}$-cAMP.

with granulosa from small follicles being most sensitive to the inhibitory effects of the ionophore $(P<0.05)$ (compare inhibition at $0.05 \mu \mathrm{g}$ ionophore dose). In granulosa from small follicles, a low dose of A23187 $(0.01 \mu \mathrm{g} / \mathrm{ml})$ resulted in progesterone values that were slightly elevated $(P<0.05)$ compared with controls receiving FSH alone.

\section{Effect of A23187 and forskolin}

Concentrations of oestradiol were inhibited by A23187 $(P<0.05)$ in granulosa from small- and medium-sized follicles (Fig. 3a), whereas values were enhanced in granulosa from large follicles compared with the forskolin control $(P<0.05)(1.5$-fold increase). The ionophore more potently inhibited forskolin-induced oestradiol from small follicles compared with granulosa from mediumsized follicles $(P<0.05)$ (compare inhibition at $0.1 \mu \mathrm{g}$ ionophore dose). A23187 inhibited progesterone concentrations in granulosa from follicles of all sizes compared to their appropriate forskolin-treated controls $(P<0.05)$. Progesterone was inhibited to a greater extent in granulosa from small follicles when compared with the $\%$ decrease in medium- or large-sized follicles $(P<0.05)$ (compare inhibition at $0 \cdot 1 \mu \mathrm{g}$ ionophore dose). from Bioscientifica.com at 04/26/2023 09:52:19AM 

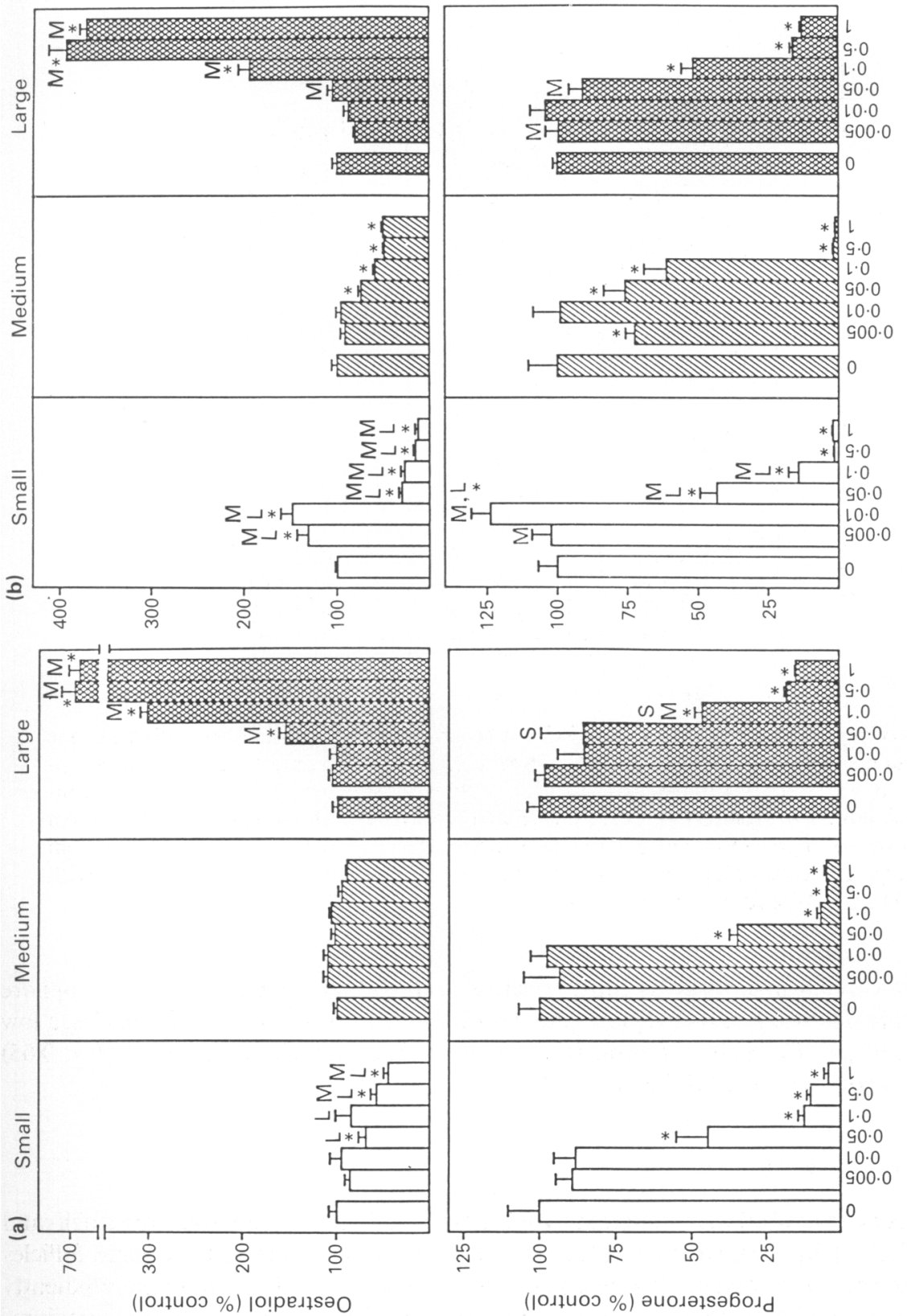

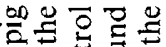

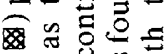

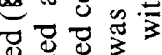
过范范 品 5 I 고 密乐

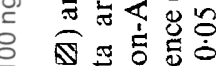
$\mathbb{S}$ 覀

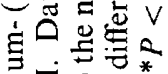

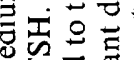
도 可 궁

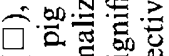
$+\varepsilon$

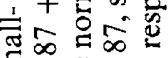

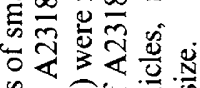

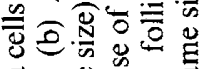

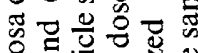

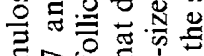
مo

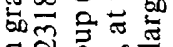

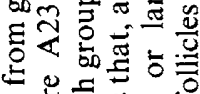

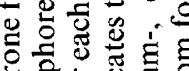

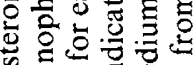

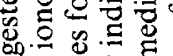
园 중

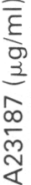

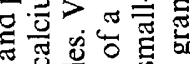
응

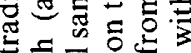

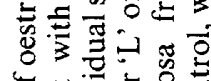

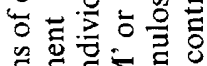

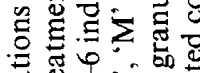

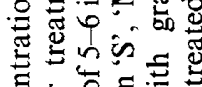

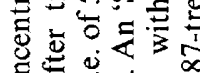
ठํㅎㅇ نे

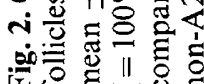



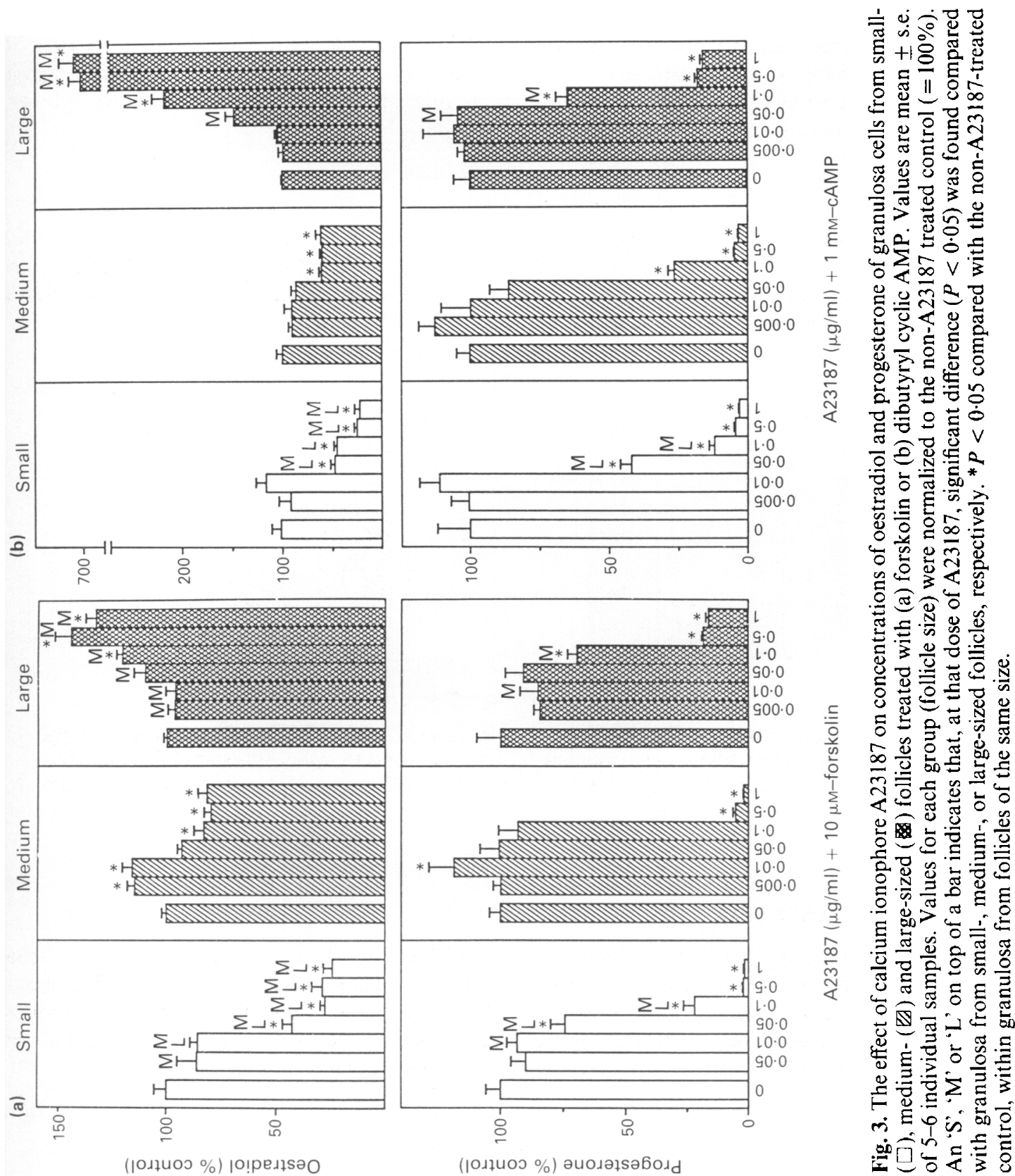

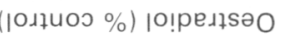

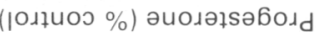




\section{Effect of A23187 and cAMP}

Cyclic AMP-induced secretion of oestradiol was significantly inhibited in granulosa cells from both small- and medium-sized follicles compared with their respective cAMP controls (Fig. $3 \mathrm{~b}$ ). This inhibition (as a \% of control) was greater in cells from small follicles $(P<0.05)$. Granulosa cells from large follicles, however, demonstrated increases of oestradiol levels in response to A23187 compared to controls treated with cAMP alone (7-fold increase). A23187 caused a significant, dose-dependent inhibition of progesterone in granulosa cells from follicles of all sizes compared to their respective cAMP-controls $(P<0.05)$.

\section{Effect of TPA}

The phorbol ester TPA produced a dose-dependent increase (5-fold) in oestradiol production and decrease in secretion of progesterone $(P<0.05)$ (Fig. 4). The TPA analogue, which does not activate protein kinase $\mathrm{C}$, had no significant effect on concentrations of oestradiol or progesterone compared to their respective controls.

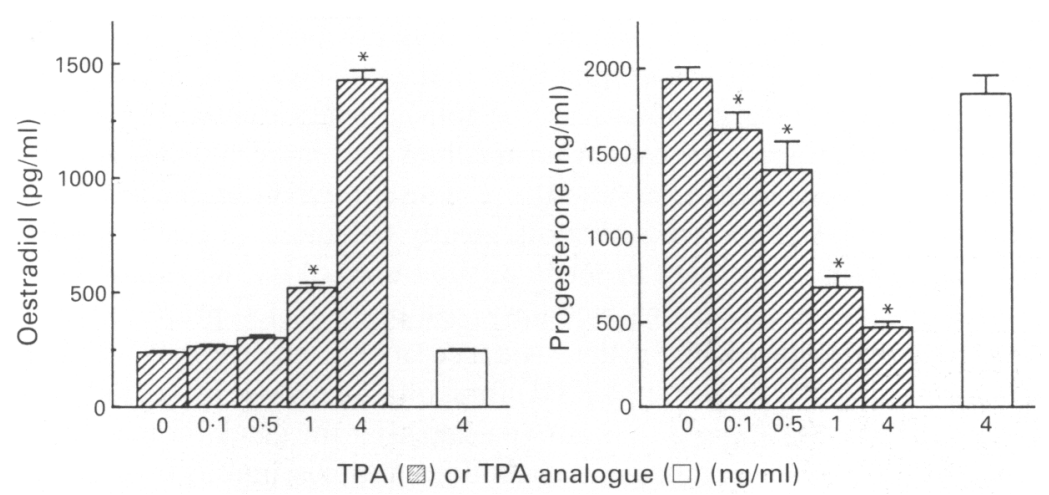

Fig. 4. Concentrations of oestradiol and progesterone in cultures of granulosa cells from large pig follicles after addition of phorbol ester (TPA, $\square$ ) or inactive phorbol ester (TPA analogue, $\square$ ). Values represent the mean \pm s.e. of 5-6 individual samples. ${ }^{*} P<0.05$ versus the nonphorbol ester-treated control.

\section{Effect of TPA and FSH}

TPA significantly inhibited oestradiol values in FSH-treated cultures of granulosa cells from small and medium follicles (Fig. 5). Conversely, TPA significantly stimulated oestradiol in granulosa cells cultured from large follicles. Inactive TPA analogue had no effect in any of the groups. Additionally, oestradiol concentrations were significantly enhanced by TPA in forskolin- and cAMP-treated cultures of granulosa cells from large follicles (data not shown).

\section{Discussion}

The studies reported in this paper demonstrated that granulosa cells from pig follicles have different steroidogenic responses to different trans-membrane signalling pathways which are dependent upon the size of the follicle. Differential steroidogenic responses were obtained when we (a) stimulated the cAMP-protein kinase A pathway (using pig FSH, forskolin, or cAMP), (b) used ionophore A23187 to raise calcium levels, or (c) stimulated protein kinase C directly with TPA 

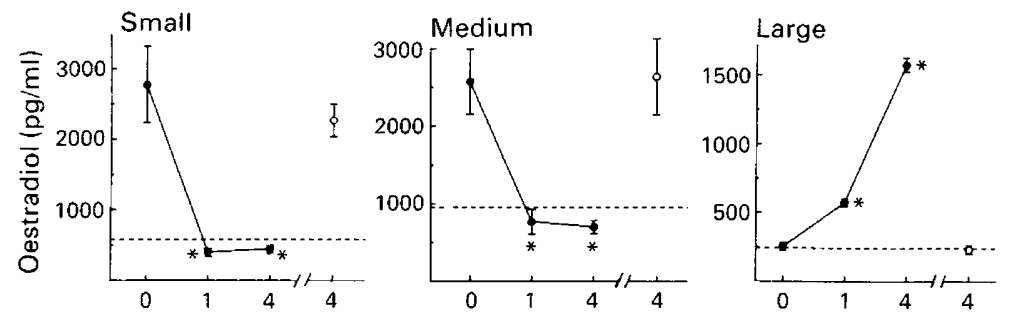

Phorbol diester (ng/ml)

Fig. 5. The effect of TPA or TPA analogue on concentrations of oestradiol in FSH-treated (100 ng) cultures of granulosa cells from small-, medium- and large-sized pig follicles. Values represent mean \pm s.e. of 5-6 individual samples. Broken line represents mean values of oestradiol in cultures not treated with FSH. ${ }^{*} P<0.05$ versus controls not treated with any phorbol ester.

Granulosa cells from pig follicles of different sizes maintain different steroidogenic responses to gonadotrophic stimuli. It appears that granulosa cells from small antral follicles are more sensitive (i.e. highest \% increases over basal) to the steroidogenic effects of FSH, forskolin or cAMP when compared with cells from medium-sized follicles. The only exception was an equipotent enhancement of progesterone (above control values) by FSH in these two groups. Since FSH and LH may share the cAMP pathway in pig granulosa as the follicle nears ovulation (Richards, 1979), it suggests that the relative response of cells from medium and large follicles to $\mathrm{LH}$ is increased (compared to FSH) as the follicle matures (and the response to FSH diminishes). Lee (1976) found that hCG-stimulated adenylate cyclase activity is greatly enhanced in pig granulosa from large follicles compared with cells from small or medium sized ones. Also, Kolena \& Channing (1971) demonstrated that granulosa cells from medium-sized pig follicles produced more cAMP in response to LH compared with FSH. Further evidence of this 'change-over' is suggested by the poor (or lack of) steroidogenic response to FSH, forskolin or cAMP by granulosa cells of large follicles. This 'shift' in response appears to occur at a step after the generation of cyclic AMP, since addition of cAMP to cultures still resulted in an enhanced response in cells from small follicles, but little or no response from basal in cells from large follicles.

The only exception to these patterns was the significant stimulation of oestradiol production by granulosa from large pig follicles after addition of forskolin. In granulosa cells from large follicles, forskolin, a diterpene which directly affects G-proteins in certain cell types (Schimmer et al., 1987), may be cross-reacting with other G-proteins which directly stimulate the PKC pathway via activation of phospholipase C breakdown of phospholipids (Spiegel, 1987; Graziano \& Gilman, 1987). (This type of co-operation between signal transduction systems has been shown previously for ovarian granulosa cells [Hertelendy et al., 1989].) Stimulation of PKC could enhance oestradiol production, since both ionophore $\mathrm{A} 23187$ (one action of which is indirect stimulation of PKC) and TPA (a more specific PKC activator) also enhance oestradiol production by granulosa cells from large pig follicles (see Figs 2-5). Forskolin is therefore either working through this postulated mechanism or some other non-cAMP regulated pathway, since direct cAMP stimulation does not stimulate oestradiol production from granulosa cells cultured from large pig follicles in serum-free conditions.

Addition of calcium ionophore A23187 to granulosa cell cultures also demonstrated differences in effectiveness depending on the maturational state of the follicle. Raising the levels of intracellular calcium (one effect of which is indirect stimulation of protein kinase $\mathrm{C}$ activity) might inhibit gonadotrophin-induced steroidogenesis more in granulosa cells from the small follicles (since cells from small follicles are stimulated by cAMP agonists). This is what was observed (see Figs $2 b$ \& 3 ).

The inhibitory effects of A23187 on FSH/cAMP-induced steroidogenesis of granulosa from small- and medium-sized follicles are similar to results previously seen in our laboratory using the phorbol ester TPA in place of the ionophore. Although it may be argued that raising intracellular 
calcium via A23187 produces effects other than on the protein kinase C pathway (i.e. calciumcalmodulin), our previous data (Hylka et al., 1989) and those in Fig. 5, show that results identical to the effects of A23187 are obtained for granulosa cells from small- and medium-sized follicles if the PKC activator TPA is substituted for A23187. Additionally, the inhibitory nature of A23187 on progesterone production by pig granulosa has been demonstrated by others with granulosa cells cultured in the presence of serum (Veldhuis et al., 1987). Our results therefore suggest that the effects of A23187 described in the present report may be due to activation of PKC. Additionally, since A23187 had identical results on FSH-, forskolin- or cAMP-treated cultures, it appears that A23187 exerts its effects at some step after the generation of cAMP.

An unexpected result from the present study was the A23187-stimulated production of oestradiol by granulosa from large follicles. Oestradiol was stimulated 4-7 times basal levels (Figs $2 \& 3$ ), even after stimulation with FSH (cAMP did not significantly elevate oestradiol in these cells [see Fig. 1]). The only exception to this enhancement occurred with concomitant forskolin treatment, when values of oestradiol were only increased $1 \cdot 5$-fold (forskolin-treated cells already have elevated oestradiol levels).

To provide more evidence that the stimulated levels of oestradiol in granulosa cells from large follicles by A23187 were actually due to PKC activation and not some other calcium or calciumcalmodulin mediated event, we performed similar experiments on cells from small, medium, and large follicles using the phorbol ester TPA (Figs $4 \& 5$ ). The results were identical to those of A23187 for these cells, suggesting that the enhanced oestradiol in granulosa cells from large follicles may have resulted from activation of protein kinase $C$.

Our results suggest that the aromatase enzyme system may be stimulated by activators of protein kinase $\mathrm{C}$ in granulosa cells from large pig follicles. Using a pool of granulosa cells from small + medium-sized follicles cultured with $1 \%$ fetal calf serum, Veldhuis \& Demers (1986) observed no effect of TPA on aromatization of testosterone. In these same experiments, TPA was shown to inhibit basal as well as FSH- and forskolin-stimulated production of progesterone, although granulosa cells from large follicles were not investigated. In experiments performed on cultured pig theca cells, we found that oestradiol production was also enhanced in cells from large follicles by TPA or A23187, whereas these same agents caused inhibition of oestradiol in theca cultured from medium-sized follicles (Hylka \& Tonetta, 1988). It is tempting to speculate that, as the follicle nears ovulation, there is a shift in the intracellular 'metabolism' such that protein kinase $\mathrm{C}$ (and/or some other calcium-mediated event) activates mechanisms which, in turn, enhance oestradiol production. Consistent with this hypothesis, TPA activation of protein kinase $\mathrm{C}$ in human granulosa-luteal cell preparations has been shown to stimulate production of cAMP (Jalkanen et al., 1987). Alternatively, Veldhuis \& Demers (1986) and Wheeler \& Veldhuis (1988) have shown no change in cAMP levels when cultured pig granulosa cells were exposed to TPA, and Wheeler \& Veldhuis (1988) observed that TPA inhibited cAMP in FSH- and forskolin-treated pig granulosa cells after 2 days of culture. Both of these studies, however, included serum in their cultures. We did not measure cAMP in our cultures.

Alternatively, if A23187 and TPA are activating PKC to enhance oestradiol levels in granulosa cells of large follicles, it is possible that, as ovulation approaches, another 'subspecies' of PKC is expressed, the activities of which may be very different from those of PKC in granulosa cells from small follicles. Different activities of these PKCs might result in the shift from inhibitory (small follicle) to stimulatory effects (large follicle) on oestradiol production. The possibility of 'temporal compartmentalization' due to PKC isoenzymes has been postulated by Wheeler \& Veldhuis (1989), who found at least three distinct PKC isoenzymes in the pig ovary. A shift in the ability of protein kinase $\mathrm{C}$ to enhance the production of oestradiol before ovulation is consistent with the increased concentrations of circulating oestradiol that occur before ovulation in the pig (Foxcroft \& Hunter, 1985).

The increased sensitivity of granulosa cells from small follicles to the anti-gonadotrophic effects of A23187 and TPA is consistent with the hypothesis that factors of extra-or intra-ovarian origin 
may limit follicular responses to gonadotrophins (Tonetta \& diZerega, 1989). Anti-gonadotrophic agents have been suggested as playing a role in atresia (Tonetta \& diZerega, 1986). Since a large amount of atresia occurs as the follicle traverses the pre-antral to antral stage, granulosa cells from small follicles might be expected to be more sensitive to the anti-gonadotrophic effects of protein kinase $\mathrm{C}$ activators. Exactly which endogenous factors might regulate the inhibitory effects of $\mathrm{PKC}$ in the young follicle and the stimulatory effects of $\mathrm{PKC}$ in the large preovulatory follicle, remain to be determined.

We thank Mae Gordon for expert word processing assistance; and Dr Sharon Tonetta, Robin DeVinna and Teresa Swart for reading an earlier version of this manuscript.

\section{References}

Ainsworth, L., Tsang, B.K., Downey, B.R., Marcus, G.J. \& Armstrong, D.T. (1980) Interrelationships between follicular fluid steroid levels, gonadotropin stimuli, and oocyte maturation during preovulatory development of porcine follicles. Biol. Reprod. 23, 621-627.

Foxcroft, G.R. \& Hunter, M.G. (1985) Basic physiology of follicular maturation in the pig. J. Reprod. Fert. Suppl. 33, 1-19.

Graziano, M.P. \& Gilman, A.G. (1987) Guanine nucleotide-binding proteins: mediators of transmembrane signaling. Trends Pharmacol. Sci. 8, 478-481.

Hertelendy, F., Nemecz, G. \& Molnar, M. (1989) Influence of follicular maturation on lutenizing hormone and guanosine 5'-O-thiotriphosphatepromoted breakdown of phosphoinositides and calcium mobilization in chicken granulosa cells. Biol. Reprod. 40, 1144-1151.

Hillier, S.G., van den Boogaard, A.M.J., Reichert, L.E., Jr \& van Hall, E.V. (1980) Intraovarian sex steroid hormone interactions and the regulation of follicular maturation: aromatization of androgens by human granulosa cells in vitro. J. clin. Endocr. Metab. 50, 640647.

Hylka, V.W. \& diZerega, G.S. (1988) Stimulation of the protein kinase $\mathrm{C}$ pathway by calcium ionophore A23187: Differential effects on steroidogenesis of granulosa cells from small, medium, and large porcine follicles. Biol. Reprod. (Suppl. 1) 38, 102, abstr.

Hylka, V.W. \& Tonetta, S.A. (1988) Porcine theca cells: effects of calcium ionophore and phorbol esters on basal and hCG-stimulated steroidogenesis. Endocrinology 112 (Suppl.), 290, Abstr. 1080.

Hylka, V.W., Kaki, M.K. \& diZerega, G.S. (1989) Steroidogenesis of porcine granulosa cells from small and medium-sized follicles: effects of folliclestimulating hormone, forskolin, and adenosine $3^{\prime}, 5^{\prime}$ monophosphate versus phorbol ester. Endocrinology 124, 1204-1209.

Jalkanen, J., Ritvos, O., Huhtaniemi, I., Stenman, U-H., Laatikainen, T. \& Ranta, T. (1987) Phorbol ester stimulates human granulosa-luteal cell cyclic adenosine $3^{\prime}, 5^{\prime}$-monophosphate and progesterone production. Molec. cell Endocrinol. 51, 273-276.

Kolena, J. \& Channing, C.P. (1971) Stimulatory effects of gonadotropins on the formation of cyclic adenosine $3^{\prime}, 5^{\prime}$-monophosphate by porcine granulosa cells. Biochim. Biophys. Acta 252, 601-606.
Lee, C.Y. (1976) The porcine ovarian follicle: III. Development of chorionic gonadotropin receptors associated with increase in adenyl cyclase activity during follicle maturation. Endocrinology 99, 42-48.

Richards, J.S. (1979) Hormonal control of ovarian follicular development. Recent Prog. Horm. Res. 35, 343-373.

Schimmer, B.P., Tsao, J., Borenstein, R. \& Endreny, L. (1987) Forskolin-resistant Y1 mutants harbor defects associated with the guanyl nucleotide-binding regulatory protein $\mathrm{G}_{\mathrm{s}}$. J. biol. Chem. 262, $15521-15526$.

Skinner, M.K. \& Osteen, K.G. (1988) Developmental and hormonal regulation of bovine granulosa cell function in the preovulatory follicle. Endocrinology 123, $1668-1675$.

Spiegel, A. (1987) Signal transduction by guanine nucleotide binding proteins. Molec. cell Endocrinol. 49, $1-16$.

Steel, R.G.D. \& Torrie, J. (1980) Principles and Procedures of Statistics. A Biometrical Approach, 2nd edn. McGraw-Hill, Inc., New York.

Tonetta, S.A. \& diZerega, G.S. (1986) Paracrine regulation of follicular maturation in primates. Clin. Endocrinol. Metab. 15, 135-156.

Tonetta, S.A. \& diZerega, G.S. (1989) Intragonadal regulation of follicular maturation. Endocrine Rev. 10, 205-229.

Tsang, B.K., Ainsworth, L., Downey, B.R. \& Marcus, G.J. (1985) Differential production of steroids by dispersed granulosa and theca interna cells from developing preovulatory follicles of pigs. J. Reprod. Fert. 74, 459-471.

Tsonis, C.G., Carson, R.S. \& Findlay, J.K. (1984) Relationships between aromatase activity, follicular fluid oestradiol-17 $\beta$ and testosterone concentrations, and diameter and atresia of individual ovine follicles. J. Reprod. Fert. 72, 153-163.

Veldhuis, J.D. \& Demers, L.M. (1986) An inhibitory role for the protein kinase $\mathrm{C}$ pathway in ovarian steroidogenesis. Studies with cultured swine granulosa cells. Biochem. J. 239, 505-511.

Veldhuis, J.D., Demers, L.M., Azimi, P., Juchter, D. \& Garmey, J. (1987) Activation of protein kinase C is coupled to prostaglandin $F_{2 a}$ synthesis in the ovary: studies in cultured swine granulosa cells. Molec. cell Endocrinol 49, 249-254. 
Wheeler, M.B. \& Veldhuis, J.D. (1988) Interactions of protein kinase $\mathrm{C}$ with receptor- and non-receptormediated cyclic AMP generation in swine granulosa cells. Molec. Cell. Endocrinol. 59, 195-203.

Wheeler, M.B. \& Veldhuis, J.D. (1989) Purification of three forms of chromatographically distinct protein kinase $\mathrm{C}$ from the swine ovary. Molec. cell. Endocr. 61, 117-122.

Received 11 August 1989 